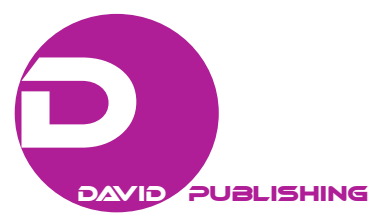

\title{
The Russian Navy is Adrift in the Syrian Doldrums
}

\author{
Pavel K. Baev \\ Peace Research Institute Oslo (PRIO), Oslo, Norway
}

\begin{abstract}
Modernization of the Russian navy started at the beginning of this decade has improved its posture but is incomplete and negatively affected by the demanding tasks related to supporting the intervention in Syria. The newly-approved naval policy sets ambitious guidelines for expanding the whole range of naval capabilities, but the yet to be approved 2027 State Armament program is set to leave these aspirations underfunded. It is possible to address the needs created by the operations in the Eastern Mediterranean, but such allocation of resources would clash with other priorities, particularly with upgrading the fleet of strategic submarines. The political demands for performing a wide range of tasks clash with the inability to set realistic targets for shipbuilding, and this bad leadership turns the Russian navy to the course of degradation. This high-risk prospect involves a range of implications for US and North Atlantic Treaty Organization (NATO) security and naval policies.
\end{abstract}

Keywords: Russia, Syria, navy, intervention, capabilities

\section{Introduction}

The unprecedented naval parade staged in St. Petersburg and Kronstadt on July 30, 2017 was supposed to demonstrate the power of the Russian navy and to present President Vladimir Putin as the resolute Commander-in-Chief, who gives the due attention to its modernization. Putin reassured the spit-and-polish admirals that the "blue ocean" navy is a key guarantor of Russia's great power status, and the first ever naval parade in Tartus, Syria was supposed to prove the global reach of four-and-a-half Russian fleets ${ }^{1}$. In fact, however, the navy is seriously over-stretched and under-resourced, and despite throwing a perfect show for Putin, who was clearly more comfortable next to the monument to Peter the Great than next to Lenin's tomb on the Red Square, it is set to take deep cuts in funding.

The open-ended intervention in Syria, which is presently the only area where a modicum of cooperation between US and Russian military exists (as well as plenty of tension), has put the navy under pressure, but the lessons learned from this combat deployment require much investment for implementation, instead of unavoidable austerity. This analysis examines the impact of the Syrian operation on the near-term prospects for modernization (and the lack of thereof) of the Russian navy.

\section{Ambitions, Priorities, and Setbacks}

One the eve of the pompous parade, Putin had signed the executive order on the Basic Principles of the State Naval Policy until 2030, which is supposed to clarify the priorities in building up the naval power in the situation of new confrontation with the West and much reduced resource base, but provides actually more

Pavel K. Baev, Research Professor, Ph.D., Peace Research Institute Oslo (PRIO); Senior Non-Resident Fellow, Brookings Institution.

${ }^{1}$ On the significance of these parades, see Bruce Jones (2017). 
muddle than clarification ${ }^{2}$. In addition to the usual maximalist goal to prepare the navy for deterring any and every threat to Russia's interest on every ocean theatre, a more specific proposition is added on countering the hostile pressure aimed at weakening Russia's control over the Northern Sea Route, which has no connection to the reality of remarkably cooperative international environment in the Arctic $^{3}$. The newly-formulated task of ensuring the position of the second most powerful in the world for the Russian navy is set to be defeated by China's massive naval build-up program (Golts, 2017). The combination of exaggerated threat assessments and entirely unrealistic guidelines on countering these threats is so bizarre that Gorenburg (2017) has good reasons for describing the new document as "yet another salvo in the ongoing rearguard action by the Russian Navy to protect its procurement budget".

The most quixotic of all impractical demands in the new policy is the reaffirmed intention to add aircraft carriers to the combat order of the Russian navy, which has been the impossible dream of its admirals since the autumnal years of the Soviet Union ${ }^{4}$. There is no shipyard capable of constructing such ships, technology is a big problem, and resources are not forthcoming. The latter part of the predicament is going to be established for fact in the 2027 Armament program, which is to be finalized before the end of 2017, three years too late ${ }^{5}$. The contents remain uncertain at the moment of this writing as the furious lobbyism continues, but it appears quite probable that the navy would take more than a fair share of cuts (Nikolsky, May 19, 2017).

The high profile for the navy in the previous 2020 Armament program was secured first of all by the heavy investments in construction of a new Borei-class (Project 955) generation of strategic nuclear submarines (SSBN), three of which are now deployed and five more in different stages of construction. Persistent problems with the Bulava missile (SS-N-32), which is the main weapon system for these submarines, could hit back at any test, as they did many times in the curtailed trial period, turning this provisional success into a costly setback (Litovkin, 2016). Concentration of resources on the Borei program caused delays with implementing the second most demanding plan: The Project 885 Yasen-class nuclear attack submarines (SSGN) ${ }^{6}$. Severodvinsk, the first in the series, entered the Northern Fleet in 2014, after 20 years of construction and trials, and the Kazan was launched in spring 2017, while five more keels have been laid down. This delay and the failure of a new Project 677 Lada-class submarine design compelled the authorities to focus on fast production of an upgraded model of Kilo-class diesel-electric attack submarines (developed in the 1970s), so six new Project 636.3 (Varshavyanka) submarines joined in 2015-2017 the Black Sea Fleet and two more are under construction for the Pacific Fleet at the St. Petersburg shipyard (another four are contracted) (Rubin, 2016).

Submarines are going to constitute the main force of the Russian navy, particularly since the plans for constructing major surface combatants are upset by a series of setbacks (Hendrix, 2017) ${ }^{7}$. The breakdown of the deal with France on purchasing two and constructing two more Mistral-class amphibious assault ships is a major blow to Russia's maritime strategy, and the assertions that these ships do not really fit into the combat order are often supplemented with pledges to build similar ships in the near future (TASS, July 28, 2017). In

\footnotetext{
2 The text (in Russian) is available at the presidential website (http://kremlin.ru/acts/bank/42117); a useful concise comment is Aleksei Nikolsky (2017, July 23).

3 This proposition was further elaborated in the Defense Ministry report on net security assessment, in which Norway alleged attempts to establish full sovereignty over Svalbard were identified as a risk factor; see Thomas Nilsen (2017) on that.

4 Transformation of this dream is examined in Tom Fedyszyn (2017).

${ }^{5}$ Lobbyists of the super-project are not giving up; see for instance, Grigory Naberezhniv (2017).

${ }^{6}$ Western assessments of this project are often rather inflated; see, for instance, Dave Majumdar (2017, March 15).

7 This fits the traditional Soviet pattern, and constitutes a familiar challenge for NATO.
} 
fact, the new flagship of the Russian navy in a couple of years will be the old nuclear battle cruiser Admiral Nakhimov, coming out of protracted modernization, which awaits the worn-out Petr Velikii (Bodner, 2015).

The shift to constructing frigates (Admiral Grigorovich class) and smaller crafts is not a matter of strategic preference but of technological necessity and of the sorry state of many shipyards affected by mismanagement more than by sanctions ${ }^{8}$. What makes it possible for the naval command to make a virtue out of necessity is the possibility to deploy on such small platforms the new 3M-54 Kailbr long-range cruise missiles (Roblin, 2017), and in the near future 3M22 Zircon (SS-N-33) anti-ship missile (The Maritime Executive, 2017). These weapon systems grant even light squadrons the capability for projecting considerable firepower on shore and the capacity to threaten US joint task forces formed around aircraft carriers. The ability to perform missions far from home bases and to form "bastions" for protecting strategic submarines is set to remain limited, whatever needs the Kremlin might have in demonstrating flag or challenging the US dominance.

\section{The Syrian Test for the Navy}

The intervention into the Syrian civil war launched with great resonance in September 2015, has added a new page to the Russian military history records, even if its scale is smaller than that of Soviet "air bridges" to Egypt and Syria in the 1970s. This projection of power far beyond the immediate perimeter of Russia's borders was supposed to demonstrate, inter alia, the global reach of its Navy. The main force in this intervention is the small grouping of Russian Air-Space Forces deployed at the Khmeimim airbase outside Latakia, which generally performed above expectations, despite the recent crash (Safronov, 2017) ${ }^{9}$. The execution of the plan for corralling the rebels in the so-called "de-escalation zones" required deployment of special forces, military police, and sub-contractors (like the Wagner group), and the casualties in autumn 2017 increased accordingly (Felgengauer, 2017). The navy, nevertheless, has played a major role in supporting and executing the intervention from day one, and had to mobilize its limited capabilities, which continue to undergo tough tests.

The most important function that the navy performs is delivering supplies and providing logistical support for the intervention, and it became clear already in October 2015, that it didn't have enough ships to move the necessary cargo. Several old freighter ships were purchased in Turkey and added to the navy list as auxiliaries, so that it was possible to increase the grouping in Syria in December 2015 during the crisis caused by the intercept of a Russian Su-24M bomber by a Turkish F-16 fighter (Saul \& Tsvetkova, 2015). The pressure on naval supply ships still remains heavy, so that, for example, the 30 years old Caesar Kunikov large landing ship performed six trips between Novorossiysk and Tartus in the first half of 2017 (Riskin, 2017). The sister-ship Aleksandr Otrakovsky (40 years old) performed in 2015-2016 the longest cruise on the Northern Fleet record-588 days (RIA-Novosti, 2017). One illustration to this overstretch was the accident on 27 April 2017, when Russian naval intelligence vessel Liman sunk after collision with a livestock freighter 17 miles north of the Bosporus (Bosphorus Naval News, 2017). Additional embarrassment was caused by the revelation that its electronic equipment was of no value for the North Atlantic Treaty Organization (NATO) (Egorov, 2017).

In support of the intervention, Russian navy has also deployed a squadron in the Eastern Mediterranean, so that the Black Sea flagship cruiser Moskva (35 years old) stayed near the Syrian coast from June 2015 to

\footnotetext{
8 The disrepair of shipyards is emphasized in Dave Majumdar (2017, March 03).

9 The Su-24M bomber crashed on the take-off on October 10, 2017.
} 
January 2016, and would now have to undergo long repairs in Sevastopol (Krymova, 2017) ${ }^{10}$. The high moment in the demonstration of naval might was supposed to be the combat deployment to the Eastern Mediterranean of Russia's only aircraft carrier Admiral Kuznetsov in autumn 2016, but its performance wasn't exactly stellar. The air sorties were less effective than those performed from the Khmeimim base, two planes (Mig-29K and Su-33) were lost due to technical failures, and now the ship needs costly repairs that would take at least three years (Khodarenok, 2017) ${ }^{11}$.

The only real success achieved by the Russian navy in the Syrian operation is the series of strikes by the long-range Kalibr cruise missile, starting with the salvo by the four ships of the Caspian flotilla on 7 October 2015 (Cavas, 2005) $^{12}$. Syrian rebels hardly have any targets worth of such strikes, but the frigates and diesel-electric submarines deployed in the Eastern Mediterranean routinely perform them as a part of their patrol plan. Besides gaining experience and testing weapon systems, this pattern demonstrates Russia's new capabilities for conventional deterrence, even if, as Nikolai Sokov (2017) argues, a fully integrated system of command, control, intelligence and target acquisition is still years away. The US missile strike on the Shayrat airbase on April 6, 2017, with 59 Tomahawk missiles launched by two Arleigh Burke class destroyers (USS Ross and USS Porter), instantly revealed deficiencies in both Russian air defence "bubble" over Tartus and Latakia, and in high-precision strike capabilities (Kofman, 2017). Russian Baltic and Northern Sea fleets conducted a series of exercises as a part of the large-scale Zapad-2017 exercises in September 2017, but that determined a reduction of naval presence in the Mediterranean. The over-stretch is still denied but its impact grows heavier.

\section{Prospects and Implications}

Accumulating stress from the Syrian operation will affect the performance and combat readiness of the Russian navy for years to come, particularly if it indeed comes out as a designated loser in the curtailed 2027 Armament program. Aircraft carrier Admiral Kuznetsov and three battle cruisers (Petr Velikii, Moskva, and Varyag) are in need of overhaul and modernization, which can only be done in Severodvinsk, where Yasen-class and Borei-class nuclear submarines are also in construction, so all sorts of delays are certain to occur. The most acute problem is with amphibious ships, as the 40-45 years old Alligator series ( 3 ships) and 35-40 years old Ropucha-I series (9 ships, build in Poland) landing ships are worn out beyond repair, while the new Ivan Gren series is cut down to two ships, the first of which is still undergoing trials after 13 years of construction in the Kaliningrad shipyard (TASS, June 05, 2017). Russian naval shipbuilding is badly affected by sanctions and the interruption of cooperative ties with Ukraine, while corruption in the United Shipbuilding Corporation (OSK) is notorious even by Russian standards ${ }^{13}$.

This gradual but irreversible deterioration of naval might will have a significant impact on Russia's policy in the Middle East, which has been empowered by the Syrian intervention. This projection of air and naval power is still perceived in the region as a manifestation of Russia's intentions and capacity to claim a major political role; however, it may be soon recognized as a self-entrapment that denies Moscow the ability to

\footnotetext{
${ }^{10}$ Originally, it was scheduled to be overhauled at the more modern Severodvinsk shipyard, but the local authorities made the case with President Putin for leaving Moskva in Sevastopol, which is certain to be less efficient and more costly.

11 The original estimate of costs was about \$US 900 million, but in the updated plan it is reduced by half, so that modernization would be much reduced.

12 Another salvo was delivered on November 20, 2015, but the Caspian Flotilla has not been in action since.

${ }^{13}$ On the impact of sanctions, see Dmitry Gorenburg (2015).
} 
engage elsewhere. For that matter, the speculations about a possible Russian intervention in the Libyan civil war fail to take into account the plain fact that the Russian navy has no capacity for supporting another operation of even a modest scale ${ }^{14}$. The protracted violent crisis in Yemen, for that matter, is clearly beyond Russia's military reach. The sustainability of the Syrian deployment also cannot be taken for granted because any accident at sea (the sinking of Liman provides an example) could expose the vulnerability of the sea lines of communication.

This weakness may be partly compensated by the expansion of Russian naval facility in Tartus, which is often presented as a full-scale base, but is in fact rather small and under-developed ${ }^{15}$. The agreement signed in January 2017 makes it possible for Russia to upgrade it, but the access would still remain conditional and can be terminated on a year notice ${ }^{16}$. As Russian navy is getting short of major surface combatants and features smaller missile platforms, it might make sense to establish a permanent base for a squadron of Karakurt-class missile corvettes (eight are currently under construction, four more are contracted) in the Eastern Mediterranean (Novichkov, March 21, 2017). That would require a considerable expansion of Tartus facilities and ensuring security of the base against terrorist attacks, like the one in May 2016 (Davison, 2016).

It is within the realm of possible to invest in the naval capabilities supporting the intervention in Syria and in building proper infrastructure in Tartus, but these demands would inevitably clash with other priorities in the diminishing share of the shrinking defense budget allocated to the navy. Completion of the Borei SSBN program is set to remain the single most expensive item in the whole 2027 Armament program, followed by the advancement of the Yasen SSGN program, so construction of amphibious and auxiliary ships most probably will be under-funded. There is also a high-priority plan for constructing ships capable of operating in the High North (Project 23550 Ivan Papanin class patrol craft), since presently the Northern Fleet doesn't have a single ice-class ship (Novichkov, April 25, 2017). Arctic ambitions are therefore implicitly clashing with Syrian ambitions, and the construction of nuclear icebreaker Arktika is, for that matter, running into delays (Vedeneeva et al., 2017) ${ }^{17}$.

Russian High Command keeps demanding resources necessary for meeting the approved strategic guidelines, and Putin remains reluctant to establish clear and reduced priorities corresponding to the economic realities, and this uncertain posture of the Russian navy generates a range of implications for the USA and NATO. One of them is the increasing probability of accidents as the ships in combat deployment, including in the Eastern Mediterranean, are pushed beyond the level of acceptable risk. A particular risk here is that hostile action might be presumed or invented in order to cover technical failures. It took firm determination from Putin to overrule the "hypothesis" of his admirals that collision with a US submarine was the cause of the SSGN Kursk catastrophe in August 2000; he might be unable to master such resolution when the next disaster strikes.

The situation when submarines constitute the main strength of Russian navy is generally familiar for the USA and NATO authorities, and there are operational and technological solutions for upgrading capabilities in anti-submarine warfare. More difficult is the emerging challenge set by the expected deployment on small platforms, as well as on submarines, of new Zircon anti-ship missile, against which there is presently no effective defense (Fedorov, 2017). A possible deployment in Tartus of the Bastion (SSC-5 Stooge) anti-ship

\footnotetext{
14 One example of such alarmism is Michael Tanchum (2017).

15 One seriously inflated assessment is Michael Peck (2017).

16 A sober Russian view is Vladimir Muhin (2017).

17 On the criminal investigation of this delay, see Anastasiya Vedeneeva, Ivan Safronov, et al. (2017).
} 
missile complex equipped with Zircon missiles could be a serious threat for US and NATO naval operations in the Eastern Mediterranean.

There is, nevertheless, a broader strategic perspective, in which the main focus of NATO efforts at containing the military threat from Russia is set on the Baltic Sea theatre, while another demanding task involves building up defenses at the less accessible Black Sea theatre. Intervention in Syria forces Moscow to divert attention and resources from these two key theatres, so that the Black Sea Fleet, for instance, cannot concentrate on the task of establishing dominance in the area of its direct responsibility and has to shoulder the task of maintaining the flow of supplies through the Turkish Straits. Russia's inability to concentrate assets on the crucial directions comes together with the inability to acknowledge the need to curtail ambitions according to the shrinking resources, and this bad leadership sets the Russian navy on the course of high-risk degradation.

\section{References}

Bodner, M. (2015, August 31). Russia's most anachronistic warship is getting an overhaul. Moscow Times. Retrieved from https://themoscowtimes.com/articles/russias-most-anachronistic-warship-is-getting-an-overhaul-49252

Bosphorus Naval News. (2017, April 27). Russian intelligence gathering ship Liman, sunk off the coast of Istanbul. Retrieved from https://turkishnavy.net/2017/04/27/russian-intelligence-gathering-ship-liman-sunk-off-the-coast-of-istanbul/

Cavas, C. P. (2015, October 11). Is Caspian Sea Fleet a game-changer? Defense News. Retrieved from https://www.defensenews.com/naval/2015/10/11/is-caspian-sea-fleet-a-game-changer/

Davison, J. (2016, May 23). Bombs kill nearly 150 in Syrian government-held cities. Reuters. Retrieved from http://www.reuters.com/article/us-mideast-crisis-syria-latakia/bombs-kill-nearly-150-in-syrian-government-held-cities-monit or-idUSKCNOYEOPB

Egorov, B. (2017). Why a sunken Russian intelligence ship was of little use to NATO. Russia Beyond the Headlines. Retrieved from https://www.rbth.com/defence/2017/05/02/why-a-sunken-russian-intelligence-ship-was-of-little-use-to-nato_754806

Fedorov, I. (2017). Zircon: The Russian missile that may render US aircraft carriers obsolete. Russia Beyond the Headlines. Retrieved from https://www.rbth.com/defence/2017/04/26/zircon-russian-missile-may-render-us-aircraft-carriers-obsolete750846

Fedyszyn, T. (2017, April 19). Russia: A land power hungry for the sea. War on the Rocks. Retrieved from https://warontherocks.com/2017/04/russia-a-land-power-hungry-for-the-sea/

Felgengauer, P. (2017, October 12). Russian mercenaries fight and die in the botched operation in Syria. Eurasia Daily Monitor. Retrieved from https://jamestown.org/program/russian-mercenaries-fight-die-botched-operation-syria/

Golts, A. (2017, August 01). The Russian navy: To deter US and to compete with China. Eurasia Daily Monitor. Retrieved from https://jamestown.org/program/the-russian-navy-to-deter-the-us-and-to-compete-with-china/

Gorenburg, D. (2015, November 27). Shipbuilding may limit Russian navy future. The Maritime Executive. Retrieved from http://www.maritime-executive.com/editorials/shipbuilding-may-limit-russian-navys-future

Gorenburg, D. (2017, July 26). Russia's new and unrealistic naval doctrine. War on the Rocks. Retrieved from https://warontherocks.com/2017/07/russias-new-and-unrealistic-naval-doctrine/

Hendrix, J. (2017, May 25). NATO must strengthen its anti-submarine capabilities to meet the Russian threat. National Review. Retrieved from http://www.nationalreview.com/article/447930/russian-naval-threat-nato-must-strengthen-anti-submarinecapabilities

Jones, B. (2017, August 01). Russia's navy sets international strategic markers. Jane's Navy International. Retrieved from http://www.janes.com/article/72763/russia-s-navy-day-sets-international-strategic-markers

Khodarenok, M. (2017, October 15). Kuznetsov is not in the same league with Washington. Gazeta.ru (in Russian). Retrieved from https://www.gazeta.ru/army/2017/10/15/10944080.shtml

Kofman, M. (2017, April 10). US cruise missile strike in Syria-Brief analysis. Russia Military Analysis. Retrieved from https://russianmilitaryanalysis.wordpress.com/2017/04/10/u-s-cruise-missile-strikes-in-syria-brief-analysis/

Krymova, Y. (2017, August 21). Cruiser Moskva will be repaired in Sevastopol. Rossiiskaya gazeta (in Russian). Retrieved from https://rg.ru/2017/08/21/reg-ufo/krejser-moskva-otremontiruiut-v-sevastopole.html 
Litovkin, N. (2017, October 23). What's wrong with Russia's new Bulava missile? Russia Beyond the Headlines. Retrieved from https://www.rbth.com/defence/2016/10/03/whats-wrong-with-russias-new-bulava-missile_635311

Majumdar, D. (2017, March 03). The Russian navy is powerful (but suffers from 2 big fatal flaws). The National Interest. Retrieved from http://nationalinterest.org/blog/the-buzz/the-russian-navy-powerful-suffers-2-big-fatal-flaws-19657

Majumdar, D. (2017, March 15). Russia's most powerful nuclear attack submarine is almost ready for sea. The National Interest. Retrieved from http://nationalinterest.org/blog/the-buzz/russias-most-powerful-nuclear-attack-submarine-ever-almost-19775

Muhin, V. (2017, January 23). Tartus will not become Russian naval base. Nezavisimaya gazeta (in Russian). Retrieved from http://www.ng.ru/world/2017-01-23/2_6909_tartus.html

Naberezhniv, G. (2017, June 28). Defense Ministry promises to develop a design for aircraft carrier by 2025. RBC.ru (in Russian).

Nikolsky, A. (2017, July 23). New Russian naval doctrine sets excessive aims. Vedomosti (in Russian). Retrieved from https://www.vedomosti.ru/politics/articles/2017/07/24/725414-voenno-morskaya-doktrina

Nikolsky, A. (2017, May 19). New State Armament program will have new priorities. Vedomosti (in Russian). Retrieved from https://www.vedomosti.ru/politics/articles/2017/05/19/690524-novoi-gosprogrammi

Nilsen, T. (2017, October 04). Russia lists Norway's Svalbard policy as a potential risk of war. Barents Observer. Retrieved from https://thebarentsobserver.com/en/security/2017/10/kommersant-russia-lists-norways-svalbard-policy-potential-risk-war

Novichkov, N. (2017, March 21). Russia expands Project 22800 missile corvette production. Jane's Defence Weekly. Retrieved from http://www.janes.com/article/68890/russia-expands-project-22800-missile-corvette-production

Novichkov, N. (2017, April 25). Russian Project 23550 Arctic patrol ship laid down. Jane's Defence Weekly. Retrieved from http://www.janes.com/article/69803/russian-project-23550-arctic-patrol-ship-laid-down

Peck, M. (2017, March 18). How Russia is turning Syria into a major naval base for nuclear warships (and Israel is worried). The National Interest. Retrieved from http://nationalinterest.org/blog/the-buzz/how-russia-turning-syria-major-naval-base-nuclear -warships-19813

RIA-Novosti. (2017, September 21). Aleksandr Otrakovsky goes through La Manche. Retrieved from https://ria.ru/defense_safety/20170921/1505210324.html

Riskin, A. (2017, July 13). Russian navy cannot support another "Syrian express". Nezavisimaya gazeta (in Russian). Retrieved from http://www.ng.ru/armies/2017-07-13/100_flot130717.html

Roblin, S. (2017, January 22). Why Russia's enemies fear the Kalibr cruise missile. The National Interest. Retrieved from http://nationalinterest.org/blog/the-buzz/why-russias-enemies-fear-the-kalibr-cruise-missile-19129

Rosbalt.ru. (2016, November 15). Who profits from repairs on Russian ships? Retrieved from http://www.rosbalt.ru/business/2016/11/15/1567033.html

Rubin. (2016, November 24). Construction of submarines for the Russian Black Sea Fleet completed. Central Design Bureau for Marine Engineering. Retrieved from http://ckb-rubin.ru/en/press_room/news_events/signle_news/news/detail/News/ construction_of_submarines_for_the_russian_black_sea_fleet_completed/

Safronov, I. (2017, October 11). The bomber was in a wrong position. Kommersant (in Russian). Retrieved from https://www.kommersant.ru/doc/3435128

Saul, J., \& Tsvetkova, M. (2015, December 15). Russia supplies Syrian mission with old cargo ships bought from Turkey. Reuters. Retrieved from https://www.reuters.com/article/us-russia-syria-ships-idUSKBNOTY2BG20151215

Sokov, N. (2017). Russia's new conventional capability: Implications for Eurasia and beyond. PONARS Eurasia Memo 472. Retrieved from http://www.ponarseurasia.org/memo/russias-new-conventional-capability-implications-eurasia-and-beyond

Tanchum, M. (2017, March 16). Russia's intervention in Libya would realign the Eastern Mediterranean. The Jerusalem Post. Retrieved from http://www.jpost.com/Opinion/Russias-intervention-in-Libya-would-realign-the-eastern-Mediterranean484419

TASS. (2017, July 28). Amphibious ships, drones and gliders: The future of the Russian navy. Retrieved from http://tass.ru/armiya-i-opk/4443710

TASS. (2017, June 05). Ivan Gren landing ship has resumed sea trials in the Baltic. Retrieved from http://tass.ru/armiya-i-opk/4313765

The Maritime Executive. (2017, March 27). Russia develops Mach six anti-ship missile. Retrieved from http://www.maritime-executive.com/article/russia-develops-mach-six-anti-ship-missile

Vedeneeva, A. et al. (2017, July 12). Arktika is adrift. Kommersant (in Russian). Retrieved from https://www.kommersant.ru/doc/3351960 